\title{
Can distal radius or vertebra fractures due to low-energy trauma be a harbinger of a hip fracture?
}

\author{
Düşük enerjili travmalardan kaynaklı distal radius veya vertebra kırıkları \\ kalça kırığı için işaret olabilir mi?

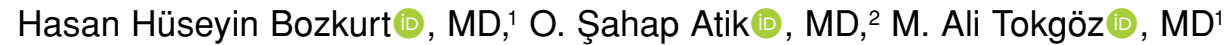 \\ 'Department of Orthopedics and Traumatology, Medicine Faculty of Gazi University, Ankara, Turkey \\ ${ }^{2}$ Professor of Orthopedic Surgery, Turkish Joint Diseases Foundation, Ankara, Turkey
}

\begin{abstract}
Objectives: This study aims to investigate whether or not low-energy distal radius or vertebra fractures are harbingers of hip fracture.

Patients and methods: A total of 142 patients had surgical treatment due to hip fracture in our clinic between February 2013 and January 2017. The patients had lowenergy fractures before hip fracture, and they received either medical treatment for osteoporosis or not before hip fracture developed.

Results: Of 142 patients, 32 had distal radius, humeral neck, ankle, vertebra fractures and 15 had a second hip fracture. The patients were determined to have most frequently a distal radius and vertebra fracture before hip fracture. The treatment of osteoporosis was determined to be neglected in 58\% of 47 patients in total who had a fracture previously.

Conclusion: Distal radius and vertebra fractures are the harbingers of a potential hip fracture. Physicians, especially orthopedists, who face with these fractures should be careful in terms of osteoporosis.
\end{abstract}

Keywords: Awareness; osteoporosis; osteoporotic fracture.

The incidence of osteoporosis in society is increasing depending on many factors such as increased ratio of the elderly population with prolonged life expectancy, sedentary lifestyle, and malnutrition. ${ }^{[1,2]}$ An important outcome of osteoporosis, an important public health problem, is fractures which particularly result in increased

\section{ÖZ}

Amaç: Bu çalışmada, düşük enerjili distal radius veya vertebra kırıklarının kalça kırığ 1 için işaret olup olmadığı araştırıldı.

Hastalar ve yöntemler: Kliniğimizde Şubat 2013 - Ocak 2017 tarihleri arasında toplam 142 hastaya kalça kırı̆̆ nedeniyle cerrahi tedavi uygulandı. Hastalar kalça kırığı öncesi düşük enerjili kırıklara sahipti ve kalça kırığı gelişmeden önce osteoporoz için medikal tedavi alanlar da vardı almayanlar da.

Bulgular: Yüz kırk iki hastanın 32'sinde distal radius, humerus boynu, ayak bileği, vertebra kırıkları ve 15 'inde ikinci kalça kırığı vardı. Hastaların kalça kırığı öncesi en sık distal radius ve omur kırığı olduğu belirlendi. Daha önce kırı̆̆ı olan toplam 47 hastanın \%58'inde osteoporoz tedavisini ihmal ettikleri belirlendi.

Sonuç: Distal radius ve vertebra kırıkları, potansiyel kalça kırı̆̆ı için işarettir. Bu kırıklar ile yüz yüze gelen hekimler, özellikle ortopedi uzmanları, osteoporoz açısından dikkatli olmalıdırlar.

Anahtar sözcükler: Farkındalık; osteoporoz; osteoporotik kırık.

morbidity and mortality. If osteoporosis is not prevented or detected early and appropriate medical treatment is not administered, relevant health expenditure is expected to increase. ${ }^{[2]}$

Orthopedics and traumatology specialists have become increasingly aware of surgical treatment of osteoporotic fractures, however, this is not the case for 
TABLE I

Demographic data of patients with and without minor fracture before hip fracture

\begin{tabular}{|c|c|c|c|c|c|c|c|}
\hline & \multicolumn{3}{|c|}{ Those without minor fracture $(n=110)$} & \multicolumn{3}{|c|}{ Those with minor fracture $(n=32)$} & \multirow[b]{2}{*}{$p$} \\
\hline & $\mathrm{n}$ & $\%$ & Mean $\pm S D$ & $\mathrm{n}$ & $\%$ & Mean $\pm S D$ & \\
\hline Age (year) & & & $82.2 \pm 7.8$ & & & $79.9 \pm 7.6$ & $0.143^{*}$ \\
\hline Gender & & & & & & & $0.194 \ddagger$ \\
\hline Female $(n=105)$ & 78 & 74.3 & & 27 & 25.7 & & \\
\hline Male $(n=37)$ & 32 & 86.5 & & 5 & 13.5 & & \\
\hline Treatment status absent $(n=109)$ & 88 & 80.7 & & 21 & 19.3 & & \\
\hline Present $(n=33)$ & 22 & 66.7 & & 11 & 33.3 & & $0.145 \ddagger$ \\
\hline
\end{tabular}

SD: Standard deviation; * Independent Samples t-test; $\ddagger$ Continuity correction (Yates corrected) chi square test.

its medical treatment. ${ }^{[3]}$ Patients who have previously endured fracture due to low-energy trauma may have a high risk of hip fracture, and secondary prevention is very important. ${ }^{[4]}$

In our study, we aimed to answer the question, "Can distal radius or vertebra fractures that develop after low-energy trauma secondary to osteoporosis be a harbinger of a potential hip fracture?"

\section{PATIENTS AND METHODS}

Approximately 350 patients who underwent surgery in the Orthopedics and Traumatology Department of Gazi University Faculty of Medicine between February 2013 and January 2017 due to hip fractures (femoral neck, intertrochanteric, and subtrochanteric) occurring as a result of low-energy trauma were screened. Fractures occurring under 60 years of age, pathologic fractures, those with secondary osteoporosis (hyperparathyroidism, thyrotoxicosis, male hypogonadism, malabsorption syndromes, malignancy, chronic liver disease, and other secondary causes of osteoporosis), and fractures resulting from high-energy trauma were excluded. The remaining 142 patients were included in the study. The study was conducted in accordance with the principles of the Declaration of Helsinki.

The patients were mainly evaluated in two groups, namely the patients with and without distal radius, vertebra, humeral neck, and other fractures as a result of low-energy trauma before the development of hip fracture. The status of patients receiving medical treatment for osteoporosis and the efficacies of these treatments were also investigated. Other fractures apart from hip fractures were collected under the "minor" fracture group.

\section{Statistical analysis}

SPSS for Windows version 15.0 (SPSS Inc., Chicago, IL, USA) statistical package program was used for statistical analysis of the research data. In this study, the statistical significance level was accepted as $\mathrm{p}<0.05$.

\section{RESULTS}

Of 142 patients, 32 had a minor fracture before hip fracture and 15 had a second hip fracture. Only 33 of 142 patients were observed to have received medical treatment before hip fracture while 109 did not receive any treatment (Table I).

Minor fractures before hip fracture were noted to most commonly occur in vertebra and radius (31.3\%), which was followed by shoulder $(15.6 \%)$, ankle $(12.4 \%)$, and femoral fractures $(9.4 \%)$, respectively (Table II).

Medical treatment for osteoporosis had not been initiated in $40 \%$ of the patients $(n=6)$ with a second hip fracture while it was initiated in $60 \%$ of them $(n=9)$ (Table III).

\section{DISCUSSION}

Our study demonstrated that distal radius or vertebra fractures which develop after low-energy trauma may suggest the presence of underlying osteoporosis, and may lead to hip fractures. It also showed that the awareness of orthopedic surgeons of diagnosing

\section{TABLE II}

Characteristics of the patients with minor fractures

\begin{tabular}{lcc}
\hline & $\mathrm{n}$ & $\%$ \\
\hline Vertebra & 10 & 31.3 \\
Radius & 10 & 31.3 \\
Shoulder & 5 & 15.6 \\
Femur & 3 & 9.4 \\
Tibia-ankle & 4 & 12.4 \\
Total & 32 & 100
\end{tabular}


TABLE III

Demographic data of the patients with a second hip fracture

\begin{tabular}{|c|c|c|c|c|c|c|c|}
\hline & \multicolumn{3}{|c|}{ Those without a second hip fracture $(n=127)$} & \multicolumn{3}{|c|}{ Those with a second hip fracture $(n=15)$} & \multirow[b]{2}{*}{$p$} \\
\hline & $\mathrm{n}$ & $\%$ & Mean \pm SD & $\mathrm{n}$ & $\%$ & Mean \pm SD & \\
\hline Age (year) & & & $81.3 \pm 7.9$ & & & $84.9 \pm 6.4$ & $0.098+$ \\
\hline Gender & & & & & & & $0.538 \ddagger$ \\
\hline Female & 95 & 90.5 & & 10 & 9.5 & & \\
\hline Male & 32 & 86.5 & & 5 & 13.5 & & \\
\hline Treatment status absent & 103 & 94.5 & & 6 & 5.5 & & $0.001 \ddagger$ \\
\hline Present & 24 & 72.7 & & 9 & 27.3 & & \\
\hline
\end{tabular}

SD: Standard deviation; † Independent Samples t-test; $\ddagger$ Fisher's Chi-square test.

and initiating medical treatment for osteoporosis is inadequate, even after hip fractures with high morbidity and mortality.

Various studies demonstrated that orthopedists' increased awareness of osteoporosis plays an important role in reducing osteoporotic fractures. ${ }^{[5-7]}$ Increased risk secondary to fracture lasts up to 10 years. Therefore, $40-60 \%$ of the surviving men and women were observed to experience another fracture later on. ${ }^{[8]}$

In our study, a total of 47 patients (33\%), including 32 patients with minor fractures (Table I), and 15 patients with hip fractures (Table III) had another fracture later on.

Although the relationship between the previous and future fracture was established, a small number of patients were found to be treated with the goal of preventing future fractures. ${ }^{[9]}$ It was determined that medical treatment had been initiated in only 11 (34\%) of 32 patients in our study who developed minor fractures, while it was uninitiated in 21 patients $(66 \%)$ (Table I). It was identified that medical treatment was neglected in 6 of $15(40 \%)$ patients who had a second hip fracture (Table III).

Klotzbuecher et al. ${ }^{[10]}$ reported that patients with a history of fracture had increased risk for subsequent vertebra and distal radius fractures. Considering our findings, vertebra and distal radius fractures were particularly identified as the most common type of fracture before hip fracture (Table II).

The presence of fracture in the forearm was reported to increase the risk of subsequent hip fracture. ${ }^{[11]}$ It has been reported that there was increased risk of hip and vertebral fractures after forearm fractures for both genders. ${ }^{[12]}$ Endres et al. ${ }^{[13]}$ also stated that Colles fracture was associated with an increased risk of hip fracture. These are the rationale for early intervention after osteoporotic fractures to avoid recurrent fractures. ${ }^{[14]}$

In conclusion; many studies indicate that fractures with underlying osteoporosis increase the risk of subsequent fracture. Unfortunately, a majority of patients do not receive adequate evaluation and/or treatment in terms of osteoporosis risk.

Osteoporosis should be definitely brought to the mind of physicians of patients who develop low-energy distal radius and vertebra fractures and treatment should be initiated to otherwise prevent potential future fractures.

\section{Declaration of conflicting interests}

The authors declared no conflicts of interest with respect to the authorship and/or publication of this article.

\section{Funding}

The authors received no financial support for the research and/or authorship of this article.

\section{REFERENCES}

1. Dontas IA, Yiannakopoulos CK. Risk factors and prevention of osteoporosis-related fractures. J Musculoskelet Neuronal Interact 2007;7:268-72.

2. Atik OS, Gunal I, Korkusuz F. Burden of osteoporosis. Clin Orthop Relat Res 2006;443:19-24.

3. Atik OS. Has the awareness of orthopedic surgeons on osteoporosis been increased in the past decade? Eklem Hastalik Cerrahisi 2015;26:63.

4. Atik OŞ, Odluyurt M, Özcan E, Savlık S. Ulna fracture and medial meniscal tear resulting from dog-related injuries. Eklem Hastalik Cerrahisi 2017;28:137-9.

5. Øyen J, Rohde GE, Hochberg M, Johnsen V, Haugeberg G. Low-energy distal radius fractures in middle-aged and elderly women-seasonal variations, prevalence of osteoporosis, and associates with fractures. Osteoporos Int 2010;21:1247-55.

6. Shakil A, Gimpel NE, Rizvi H, Siddiqui Z, Ohagi E, Billmeier TM, et al. Awareness and prevention of osteoporosis among South Asian women. J Community Health 2010;35:392-7. 
7. Nguyen DN, O'Connell MB. Asian and AsianAmerican college students' awareness of osteoporosis. Pharmacotherapy 2002;22:1047-54.

8. Center JR, Bliuc D, Nguyen TV, Eisman JA. Risk of subsequent fracture after low-trauma fracture in men and women. JAMA 2007;297:387-94.

9. Pal B. Questionnaire survey of advice given to patients with fractures. BMJ 1999;318:500-1.

10. Klotzbuecher CM, Ross PD, Landsman PB, Abbott TA, Berger M. Patients with prior fractures have an increased risk of future fractures: a summary of the literature and statistical synthesis. J Bone Miner Res 2000;15:721-39.

11. Kanis JA, Johnell O, De Laet C, Johansson H, Oden A,
Delmas P, et al. A meta-analysis of previous fracture and subsequent fracture risk. Bone 2004;35:375-82.

12. Cuddihy MT, Gabriel SE, Crowson CS, O'Fallon WM, Melton LJ. Forearm fractures as predictors of subsequent osteoporotic fractures. Osteoporos Int 1999;9:469-75.

13. Endres HG, Dasch B, Maier C, Lungenhausen $M$, Smektala R, Trampisch HJ, et al. Diagnosis and treatment of osteoporosis in postmenopausal women with distal radius fracture in Germany. Curr Med Res Opin 2007;23:2171-81.

14. Atik OŞ. What is the rationale for early intervention after osteoporotic fractures to avoid recurrent fractures? Eklem Hastalik Cerrahisi 2016;27:1. 